\title{
Anaerobic oxidations of cysteate: degradation via L-cysteate: 2 -oxoglutarate aminotransferase in Paracoccus pantotrophus
}

Department of Biology The University, D-78457 Konstanz, Germany

\author{
Carola A. R. M. Mikosch, Karin Denger, Eva-Maria Schäfer \\ and Alasdair M. Cook
}

Author for correspondence: Alasdair Cook. Tel: +497531 88 4247. Fax: +497531882966. e-mail: Alasdair.Cook@uni-konstanz.de

\begin{abstract}
Anoxic, fresh-water enrichment cultures to oxidize different organosulfonates were set up with nitrate, ferric iron or sulfate as electron acceptors. Pure cultures were easily obtained with two naturally occurring sulfonates, cysteate (2-amino-3-sulfopropionate) and taurine (2-aminoethanesulfonate), under nitrate-reducing conditions. These two sulfonates were also oxidized during reduction of iron(III), though isolation of pure cultures was not successful. One nitrate-reducing cysteate-oxidizing bacterium, strain NKNCYSA, was studied in detail. It was identified as Paracoccus pantotrophus. Eighteen sulfonates were tested, and the organism degraded cysteate, taurine, isethionate (2-hydroxyethanesulfonate), sulfoacetate or 3-aminopropanesulfonate with concomitant reduction of nitrate, presumably to molecular nitrogen. The carbon skeleton of these substrates was converted to cell material and, presumably, $\mathrm{CO}_{2}$. The amino group was released as ammonia and the sulfono moiety was recovered as sulfate. Cell-free extracts of $P$. pantotrophus NKNCYSA contained constitutive L-cysteate: 2-oxoglutarate aminotransferase (EC 2.6.1.-) and glutamate dehydrogenase (EC 1.4.1.4). Taurine:pyruvate aminotransferase, in contrast, was inducible.
\end{abstract}

Keywords: sulfonates, cysteate, anaerobic desulfonation, nitrate reduction, Paracoccus pantotrophus

\section{INTRODUCTION}

Cysteate (2-amino-3-sulfopropionate, Fig. 1) was first observed in biological systems as a weathering product from cysteine in wool (Consden et al., 1946), but it is now better known as an intermediate in one pathway of taurine (2-aminoethanesulfonate, Fig. 1) formation (Huxtable, 1992) or as a precursor (Koshikawa et al., 1981) of the major spore component, sulfolactate (Bonson et al., 1969).

The degradation of cysteate as a carbon and energy source by aerobic bacteria and fungi has been reported (Braun \& Fromageot, 1962; Stapley \& Starkey, 1970) and the compound is also known to serve as a sulfur source for such micro-organisms (Seitz \& Leadbetter, 1995), but little is known about the reactions involved.

There appear to be no reports of the accumulation of naturally occurring sulfonates under anoxic conditions, but until recently this area was not explored. Cysteate was first reported to serve as a sulfur source for fermentative growth (Chien et al., 1995) and then as an electron acceptor in respiration (Lie et al., 1996, 1998; Laue et al., 1997b). Cysteate is also subject to fermentation (Laue et al., 1997a) and its anaerobic oxi-

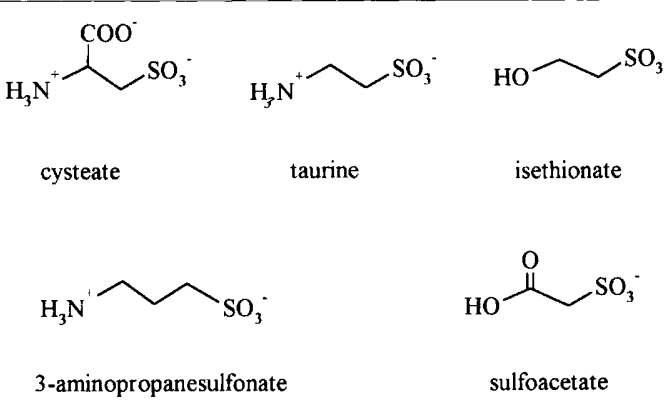

Fig. 1. The structures of cysteate (2-amino-3-sulfopropionate), taurine (2-aminoethanesulfonate), isethionate (2-hydroxyethanesulfonate), 3-aminopropanesulfonate and sulfoacetate. 
dation has been detected (Denger et al., 1997a). As with the aerobic organisms, however, no information on the degradative pathway(s) of cysteate is available. The metabolism of sulfonates has been reviewed recently (Lie et al., 1998; Cook et al., 1998).

Work with taurine and isethionate (2-hydroxyethanesulfonate, Fig. 1) indicates that their reduction in anaerobic respirations is widespread in nature, as is the fermentation of taurine (Laue et al., 1997b; Lie et al., 1998; Denger et al., 1999). In this paper we explore the range of anaerobic oxidations of cysteate with the most common environmental electron acceptors, nitrate, sulfate and iron(III), and indicate the first metabolic reaction in its oxidation coupled to nitrate reduction.

\section{METHODS}

Materials. Commercial chemicals were of high purity (about $99 \%$ ) from TCI, Sigma-Aldrich, Fluka or Merck and they were used as supplied by the manufacturer. Sulfoacetate was from Fisher Scientific. Gases $\left(\mathrm{N}_{2}, \mathrm{CO}_{2}, \mathrm{H}_{2}\right)$ were obtained from Messer Griesheim. Amorphous iron oxyhydroxide was prepared from a solution of $\mathrm{FeCl}_{3}$ as described by Schwertmann \& Cornell (1991). Standard solutions of iron were purchased from Fluka. Authentic 3-sulfopyruvate was kindly supplied by R. H. White (cf. White, 1986).

The inocula for enrichment cultures were anaerobic sludges from the anaerobic digestors of the communal wastewater treatment plants in Konstanz and Moos, south Germany. The mixed culture, NKNCYSA, from which strain NKNCYSA was isolated, was from earlier work (Denger et al., 1997a). The isolation was done under strictly anoxic conditions (resazurine indicator colourless; Denger et al., 1997a). A strain of Paracoccus pantotrophus (DSM 65) was obtained from the DSMZ (Braunschweig, Germany).

Growth media and isolation of pure cultures. Enrichment cultures were done in a basal salts medium representing fresh water, prepared anoxically as described by Widdel \& Pfennig (1981). The basal salts were buffered with $50 \mathrm{mM} \mathrm{NaHCO}$, and supplemented with trace element solution SL 10 (Widdel et al., 1983), a selenite/tungstate solution (Tschech \& Pfennig, 1984), a seven-vitamin solution (Pfennig, 1978) and, for sulfate-reducing enrichments, with titanium(III) nitrilotriacetate (to about $1.0 \mathrm{mM}$ ) as reductant (cf. Denger et al., 1996). The medium contained $200 \mu \mathrm{M}$ sodium sulfide as a source of sulfur. The $\mathrm{pH}$ of the medium was adjusted to $7 \cdot 0-7 \cdot 1$ and $25 \mathrm{ml}$ portions were transferred to $50 \mathrm{ml}$ infusion bottles, gassed with an atmosphere of $\mathrm{N}_{2}$ plus $\mathrm{CO}_{2} \quad(80: 20$, $\mathrm{v} / \mathrm{v})$ and sealed with butyl rubber septa. Nitrate $(20 \mathrm{mM})$, sulfate $(10 \mathrm{mM})$ or iron(III) $(50 \mathrm{mM})$ were added as electron acceptor. The organosulfonate concentration was $20 \mathrm{mM}$, or $6 \mathrm{mM}$ in the case of octylbenzenesulfonate, and the inoculum $(5 \%, v / v)$ was untreated anaerobic sludge. Cultures were incubated at $30^{\circ} \mathrm{C}$ in the dark. Pure cultures were obtained by the repeated application of the agar shake method (Pfennig, 1978). Culture purity was checked microscopically and by growth tests on complex media (AC-medium and Plate Count Agar; Difco).

Growth experiments and the preparation of cell-free extracts. Growth experiments with strain NKNCYSA were done in medium containing the strong reductant titanium(III) nitrilotriacetate $(1 \mathrm{mM})$ to ensure anoxic conditions. When ammonium ion was to be quantified, the basal medium was altered to contain $0.5 \mathrm{mM}$ ammonium ion instead of $4.7 \mathrm{mM}$. Samples were taken at intervals through the septum by syringe. Growth was followed routinely by measuring the optical density at $580 \mathrm{~nm}$ and quantified by determination of protein by a Lowry-type method (Cook \& Hütter, 1981). Substrate tests and mass balances were done with $10 \mathrm{ml}$ cultures in $20 \mathrm{ml}$ tubes. Chemolithoautotrophic growth was checked with $\mathrm{H}_{2} / \mathrm{CO}_{2}(80: 20, v / v)$ in the gas phase. Cells for the preparation of cell-free extracts were harvested anoxically $(2000 \mathrm{~g}$, $20 \mathrm{~min}, 4^{\circ} \mathrm{C}$ ) at the end of the exponential-growth phase and disrupted by three passages through a chilled French pressure cell $(140 \mathrm{MPa})$. Whole cells and debris were removed by centrifugation $\left(3000 \mathrm{~g}, 20 \mathrm{~min}, 4^{\circ} \mathrm{C}\right)$. Cytochromes were assayed in cell-free extracts and in the soluble and membrane fractions obtained by ultracentrifugation $(150000 \mathrm{~g}, 2 \mathrm{~h}$, $\left.4{ }^{\circ} \mathrm{C}\right)$.

Enzyme measurements. Enzyme assays for L-cysteate:2oxoglutarate aminotransferase ( 1 or $2 \mathrm{ml}$ initial volume) were done discontinuously and they were routinely anoxic. The standard reaction mixture for cysteate degradation was incubated at $37^{\circ} \mathrm{C}$ and contained $0 \cdot 1 \mathrm{M}$ Tris/ $\mathrm{HCl}$ buffer, $\mathrm{pH}$ $8 \cdot 0$ (or $0 \cdot 1 \mathrm{M}$ potassium phosphate buffer, $\mathrm{pH} 7 \cdot 5$ ), with $5 \mathrm{mM}$ $\mathrm{MgCl}_{2}, 2 \mathrm{mM}$ cysteate, $10 \mathrm{mM}$ 2-oxoglutarate and about $0.1 \mathrm{mg}$ protein $\mathrm{ml}^{-1}$; on occasion, $5 \mathrm{mM} \mathrm{NADP}{ }^{+}$or $5 \mathrm{mM}$ $\mathrm{NAD}^{+}$and $5 \mathrm{mM}$ ADP were added. The reaction mixture for taurine degradation was buffered with $0 \cdot 1 \mathrm{M}$ Tris/ $\mathrm{HCl}$ buffer, $\mathrm{pH} 8.0$, and contained $2 \mathrm{mM}$ taurine, $10 \mathrm{mM}$ pyruvate and $0 \cdot 1 \mathrm{mM}$ pyridoxal 5 -phosphate. Glutamate dehydrogenase [EC 1.4.1.4] was assayed in $0 \cdot 1 \mathrm{M}$ Tris/ $\mathrm{HCl}$ buffer, $\mathrm{pH} 9 \cdot 0$, containing $\mathrm{MgCl}_{2}, 2$-oxoglutarate, $\mathrm{NADPH}$ and $\mathrm{NH}_{4}^{+}$, essentially as indicated by Schmidt (1974).

Analytical methods. The HPLC system used was equipped with a diode array detector and used for reverse-phase chromatography (Laue et al., 1996). Cysteate, taurine, glutamate and alanine were quantified by HPLC after derivatization with 2,4-dinitrofluorobenzene (DNFB) (Sanger, 1945) as described elsewhere (Denger et al., 1997a). 3-Sulfopyruvate was determined as the azine formed by reaction with 2(diphenylacetyl)indane-1,3-dione-1-hydrazone (Cunningham et al., 1998) after separation by HPLC with UV detection (400 $\mathrm{nm})$. A perchlorate mobile phase with a gradient of acetonitrile $(30-80 \%)$ was used (cf. Kölbener et al., 1995). Nitrite was detected with analytical test strips (Merckoquant; Merck). Nitrate, nitrite and sulfoacetate, and occasionally sulfate and sulfite, were quantified by ion chromatography with suppression and conductivity detection with Sykam apparatus (Laue et al., 1996). Sulfate was measured as the optical density of a suspension of insoluble $\mathrm{BaSO}_{4}$ (Schauder et al., 1986). Sulfite was quantified photometrically as a fuchsin complex (Kondo et al., 1982). Ammonium was assayed photometrically by the Berthelot reaction (Gesellschaft Deutscher Chemiker, 1996). Sulfide was detected as the brown precipitation with copper salts (Widdel \& Bak, 1992) and was quantified using the methylene blue method (Cline, 1969). Iron(II) was quantified colorimetrically as a ferrozine complex with absorption coefficient $\varepsilon_{562}=27900 \mathrm{M}^{-1} \mathrm{~cm}^{-1}$ (Stookey, 1970). Iron(III) was quantified as the difference between the values for iron(II) and for total iron(II), i.e. after reduction of the sample with hydroxylamine. Acetate was quantified by gas chromatography as described elsewhere (Laue et al., 1997b).

The Gram reaction was evaluated according to Gregerson (1978) and oxidase and catalase tests were carried out following standard methods (Gerhardt et al., 1994). 
A partial 16S rDNA sequence of strain NKNCYSA was determined by the DSMZ (Braunschweig, Germany), where the sequence data were aligned and compared as described by Maidak et al. (1996) and Rainey et al. (1996).

\section{RESULTS}

\section{Enrichments of anaerobic, sulfonate-oxidizing bacteria}

Anoxic enrichments cultures (30) were prepared, comprising 15 conditions, each with two different inocula. The conditions involved one of five organosulfonates, taurine, cysteate, methanesulfonate, 4-toluenesulfonate or octylbenzenesulfonate [1-(4-sulfophenyl)octane], as sole source of carbon and electrons, each with nitrate, sulfate or iron(III) as electron acceptor. We considered the following phenomena, in combination with microscopy, to represent growth : turbidity in nitrate/salts medium, blackening of the sediment in sulfate/salts medium, or alteration in the rusty precipitate to black or metallic in iron(III)/salts medium. Methanesulfonate, toluenesulfonate and octylbenzenesulfonate gave no indications of growth in 3 months and these 18 cultures were abandoned. The nitrate-reducing cultures with taurine or cysteate (four of four) could be transferred after 1 week and then subcultured every $2 \mathrm{~d}$. Putative sulfate-reducing or iron(III)-reducing enrichments with taurine or cysteate (eight of eight) were transferred after 3-4 weeks, and thereafter at 2-week intervals. After 4-5 transfers, cultures were tested for growth in the absence of the appropriate electron acceptor, which would indicate the presence of fermentative bacteria (Denger et al., 1997b; Laue et al., 1997a). If the latter were present, any changes in the morphotypes of cultures were noted, so as to evaluate the importance of sulfonate-fermenting bacteria.

Nitrate-reducing bacterial cultures, which could oxidize taurine or cysteate, were obtained easily and without fermentative organisms. One oxidizer of each sulfonate was isolated by two successive agar shake series. The taurine utilizer was morphologically similar to Alcaligenes sp. strain NKNTAU (cf. Denger et al., 1997a), whereas the cysteate utilizer resembled strain NKNCYSA (cf. Denger et al., 1997a), which was selected for further studies.

Putative sulfate-reducers able to oxidize taurine or cysteate were found to grow in the absence of sulfate, but with a change in the morphotype composition of the cultures. We interpreted this to indicate fermentation of these sulfonates in the presence of oxidative organisms. However, neither subcultures into medium with less sulfonate $(5 \mathrm{mM})$ and excess sulfate $(10 \mathrm{mM})$ to favour sulfate-reducers, nor agar-shake series led to the selection of sulfate-reducers able to oxidize these sulfonates and these cultures were abandoned (cf. Mikosch, 1997).

Enrichment cultures with taurine or cysteate as electron donor and iron(III) as putative electron acceptor showed

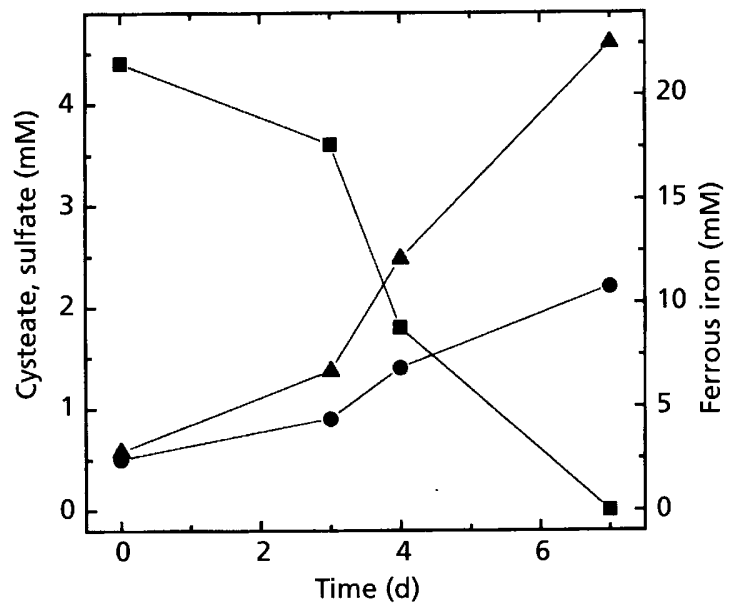

Fig. 2. Concentrations of cysteate ( $\boldsymbol{D})$, iron(II) ( $\mathbf{A})$, and sulfate (O) in mixed culture FeKNCYSA growing in cysteate/ iron(III)/salts medium. The initial culture volume was $25 \mathrm{ml}$ in a $50 \mathrm{ml}$ bottle. Data are representative values.

a reproducible change in the precipitate from rustbrown to black or shiny-metallic, in contrast to the negative controls, which were unaltered. Controls without iron showed turbidity, which presumably indicated the presence of sulfonate-fermenting bacteria. However, the enrichments with iron showed different morphotypes, mainly surrounding the iron crystals. The medium composition for the most promising culture was changed to a growth-limiting $4 \mathrm{mM}$ cysteate together with $60 \mathrm{mM}$ iron(III). A stable enrichment culture, culture FeKNCYSA, was obtained which grew out in 1 week and consisted of about three morphotypes. During growth (Fig. 2), $4.5 \mathrm{mM}$ cysteate was consumed with the production of about $2 \mathrm{mM}$ sulfate and $20 \mathrm{mM}$ iron(II); no acetate was detected. A control, involving addition of sulfide to evaluate any abiotic reduction of iron, caused negligible change in the concentration of $\mathrm{Fe}(\mathrm{II})$. There was negligible reduction of iron in the control without sulfonate and the culture did not oxidize acetate. The production of $20 \mathrm{mM}$ iron(II) can thus only be explained by oxidation of cysteate, and not as a consequence of its fermentation. Attempts to isolate the putative ironreducing, cysteate oxidizer by the agar-shake method have so far failed.

\section{Characterization and identification of strain NKNCYSA}

Strain NKNCYSA was a Gram-negative, non-motile, non-spore-forming, short $\operatorname{rod}(0.75 \times 1-1.5 \mu \mathrm{m})$, which occurred singly, in pairs and occasionally in chains. Catalase and cytochrome $c$ oxidase were present, and redox-difference spectra of cell-free extracts and of soluble fractions indicated the presence of cytochrome $c$ (maxima at 420, 522 and $551 \mathrm{~nm}$, corresponding exactly to literature data; Voet \& Voet, 1992). We tentatively 


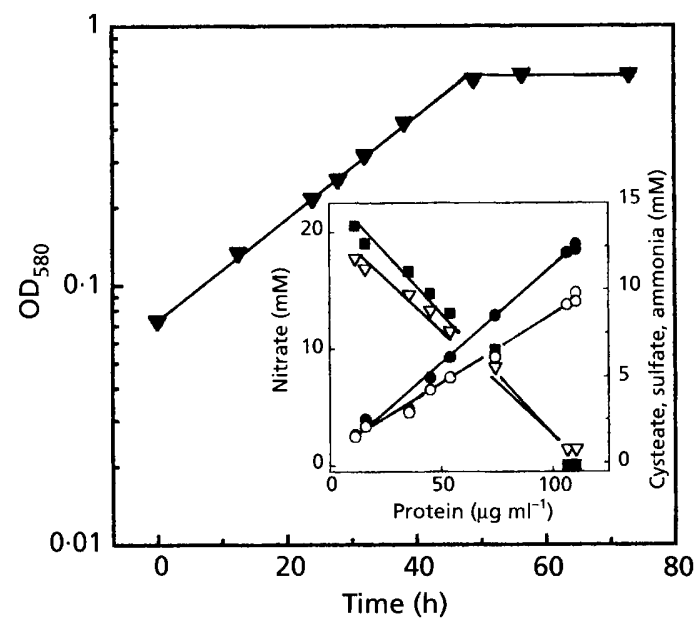

Fig. 3. Growth of $P$. pantotrophus NKNCYSA in anoxic cysteate/nitrate/salts medium. The initial culture volume was $100 \mathrm{ml}$ in a $125 \mathrm{ml}$ bottle. The growth curve $(\nabla)$ is linearized in the inset, which shows substrate disappearance and product formation as a function of growth. $\mathbf{\square}$, Cysteate; $\nabla$, nitrate; $\boldsymbol{0}$, sulfate; $\bigcirc$, ammonia. Data are representative values.

presumed an electron transport chain to be present and metabolism to be oxidative. The organism was found to be facultatively anaerobic, as it was able to utilize not only nitrate, nitrite and $\mathrm{N}_{2} \mathrm{O}$, but also oxygen as terminal electron acceptor. Neither sulfate, DMSO nor fumarate was reduced with cysteate as electron donor.

16S rDNA of strain NKNCYSA was partially sequenced and the data aligned and compared with representative organisms of the $\alpha$-subclass of proteobacteria or of the Gram-positive phylum of bacteria. The sequence was found to be $100 \%$ identical with the corresponding sequence of Paracoccus pantotrophus (Rainey et al., 1999) and the morphology and general physiology of $P$. pantotrophus correspond to those of strain NKNCYSA. Strain NKNCYSA is thus a member of this species. Strain NKNCYSA was deposited with the DSMZ (Braunschweig, Germany) as DSM 12449.

\section{Growth physiology of $P$. pantotrophus NKNCYSA}

A variety of sulfonates, related compounds and other common substrates was tested as sole electron and carbon source for strain NKNCYSA under anoxic, nitrate-reducing conditions. Cysteate, taurine, isethionate, sulfoacetate, 3-aminopropanesulfonate, pyruvate, acetate or propionate were oxidized concomitant with reduction of nitrate, whereas methanesulfonate, ethanesulfonate, 1-heptanesulfonate, cysteamine, cysteine, 2bromoethanesulfonate, coenzyme $\mathrm{M}$, benzenesulfonate, 4-toluenesulfonate, 4-sulfobenzoate, 2,6-naphthalenedisulfonate, 2-aminobenzenesulfonate, $\mathrm{N}$-cyclohexanesulfamate (cyclamate), 3-cyclohexylaminopropanesulfonate (CAPS), $N$-2-hydroxyethylpiperazine- $N^{\prime}$-2-ethane- sulfonate (HEPES), methanol or formate were not. Chemolithoautotrophic growth with $\mathrm{CO}_{2}$ and $\mathrm{H}_{2}$ was not observed. Similarly, growth was not detected with cysteate as electron acceptor and formate as electron donor (cf. Laue et al., 1997b). P. pantotrophus NKNCYSA could not ferment cysteate (cf. Laue et al., 1997a), lactate, glucose or fructose. Cysteate and taurine were utilized aerobically as sources of carbon.

P. pantotrophus DSM 65 did not oxidize cysteate, isethionate or 3-aminopropanesulfonate in anoxic nitrate/salts medium, but the organism did oxidize taurine concomitant with anaerobic growth.

Strain NKNCYSA grew exponentially $\left(\mu=0.05 \mathrm{~h}^{-1}\right)$ with cysteate as carbon and electron source and nitrate as electron acceptor (Fig. 3). Growth, measured as optical density and as protein formation, was concomitant with the utilization of cysteate and nitrate, and with the formation of sulfate and ammonia (inset). Transient traces $(\leqslant 30 \mu \mathrm{M})$ of nitrite were detected towards the end of growth and we presumed nitrate to be completely reduced to $\mathrm{N}_{2}$. We compared the stoichiometry of anoxic growth of $P$. pantotrophus NKNCYSA with three sulfonates, cysteate, taurine and isethionate, and with acetate (Table 1). The electron balance indicated that the data are a reasonable evaluation of growth, but the molar growth yields in these batch experiments varied by up to a factor of three (between cysteate and isethionate). 3-Aminopropanesulfonate was also converted to cell material, ammonia, sulfate and, presumably, $\mathrm{CO}_{2}$, whilst nitrate was reduced. However, the lag phase was up to 2 weeks and cells grew in long chains, which we attribute to some inhibitory effect of the substrate. Sulfoacetate was completely degraded under nitrate-reducing conditions and the sulfonate moiety was recovered quantitatively as sulfate.

\section{Cell-free biotransformation of cysteate}

$P$. pantotrophus NKNCYSA was grown in anoxic cysteate/nitrate/salts medium, harvested and disrupted. Anoxic supernatant fluid, after removal of whole cells and debris, was found to catalyse the 2-oxoglutaratedependent disappearance of cysteate (Fig. 4). The specific activity of the reaction was about $4-5$ mkat $(\mathrm{kg}$ protein $)^{-1},\left[0 \cdot 24-0 \cdot 30 \mathrm{U}(\mathrm{mg} \text { protein })^{-1}\right]$. Disappearance of cysteate was concomitant with the stoichiometric formation of both glutamate and 3-sulfopyruvate (Fig. 4), each of which was identified by co-chromatography with authentic material after the relevant derivatization; the relevant UV spectra were also identical. The same enzyme assay with boiled cell extract served as a control; no cysteate disappeared and no glutamate was formed. The 2-oxoglutarate could not be replaced by pyruvate. We interpret these data as proof of the existence of Lcysteate:2-oxoglutarate aminotransferase.

Ammonium ion was released during the disappearance of cysteate (Fig. 4), though not in stoichiometric amounts. This reaction was dependent on the presence 
Table 1. Stoichiometry of anoxic growth of strain NKNCYSA

Data are mean values of four replicate experiments.

\begin{tabular}{|lcccc|}
\hline Substrate & Cysteate & Taurine & Isethionate & Acetate \\
\hline Protein formed $(\mu \mathrm{g})^{*}$ & 293 & 273 & 798 & 516 \\
Substrate consumed $(\mu \mathrm{mol}) *$ & 44 & 47 & 60 & 49 \\
Substrate assimilated $(\mu \mathrm{mol}) \dagger$ & 6 & 6 & 17 & 17 \\
Substrate dissimilated $(\mu \mathrm{mol}) \neq$ & 38 & 41 & 43 & 32 \\
Nitrate consumed $(\mu \mathrm{mol})^{*}$ & 89 & 96 & 96 & 56 \\
Nitrate consumed $/$ substrate dissimilated & $2 \cdot 3$ & $2 \cdot 3$ & $2 \cdot 2$ & $1 \cdot 7$ \\
Electron balance $(\%)$ & 102 & 103 & 108 & 91 \\
Ammonia released $(\mu \mathrm{mol}) *$ & 43 & 43 & - & - \\
Ammonia assimilated $(\mu \mathrm{mol}) \dagger$ & 6 & 6 & - & - \\
Substrate nitrogen recovered $(\%)$ & 111 & 104 & - & - \\
Sulfate formed $(\mu \mathrm{mol}) *$ & 45 & 44 & 49 & - \\
Sulfur recovery $(\%) \dagger$ & 102 & 94 & 82 & - \\
Molar growth yield $\left[\mathrm{g}\right.$ protein $\left.(\mathrm{mol} \mathrm{C})^{-1}\right]$ & $2 \cdot 2$ & $2 \cdot 9$ & 6.7 & $5 \cdot 3$ \\
\hline
\end{tabular}

* Direct determination, except for isethionate.

† Calculated on the basis that cell material can be considered to be $50 \%$ protein, $50 \%$ carbon, or $14 \%$ nitrogen (Luria, 1960) and negligible sulfur, and from the following equations representing assimilatory metabolism :

$2 \mathrm{C}_{3} \mathrm{H}_{6} \mathrm{NSO}_{5}^{-}+4 \mathrm{H}_{2} \mathrm{O} \rightarrow \mathrm{C}_{6} \mathrm{H}_{12} \mathrm{O}_{6}+2 \mathrm{SO}_{4}^{2-}+2 \mathrm{NH}_{4}^{+}$

$2 \mathrm{C}_{2} \mathrm{H}_{7} \mathrm{NSO}_{3}+2 \mathrm{CO}_{2}+4 \mathrm{H}_{2} \mathrm{O} \rightarrow \mathrm{C}_{6} \mathrm{H}_{12} \mathrm{O}_{6}+2 \mathrm{SO}_{4}^{2-}+2 \mathrm{NH}_{4}^{+}+2 \mathrm{H}^{+}$

$2 \mathrm{C}_{2} \mathrm{H}_{5} \mathrm{SO}_{4}^{-}+2 \mathrm{CO}_{2}+2 \mathrm{OH}^{-} \rightarrow \mathrm{C}_{6} \mathrm{H}_{12} \mathrm{O}_{6}+2 \mathrm{SO}_{4}^{2-}$

$3 \mathrm{C}_{2} \mathrm{H}_{3} \mathrm{O}_{2}^{-}+3 \mathrm{H}^{+} \rightarrow \mathrm{C}_{6} \mathrm{H}_{12} \mathrm{O}_{6}$

Thus for synthesis of $1 \mathrm{mg}$ of protein, $22 \cdot 2 \mu \mathrm{mol}$ cysteate, taurine or isethionate, or $33 \cdot 3 \mu \mathrm{mol}$ acetate were consumed.

$\ddagger$ Calculated as the difference between total consumption and assimilation.

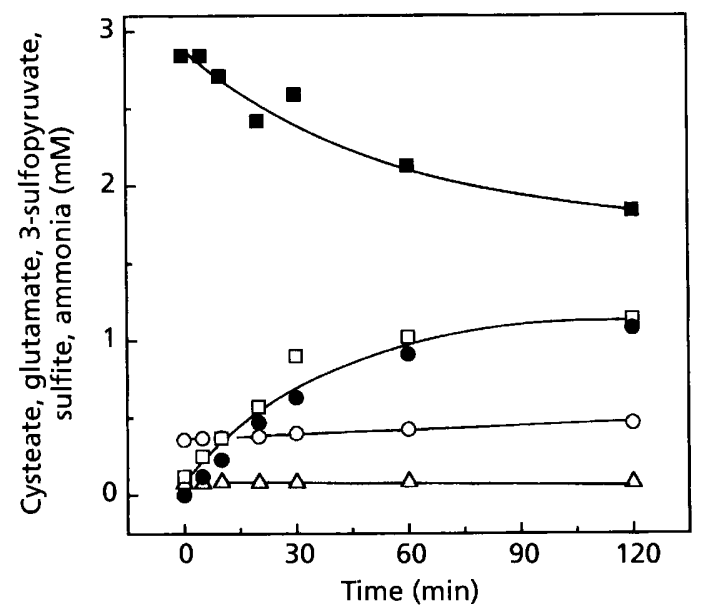

Fig. 4. Transformation of cysteate $(\boldsymbol{D})$ in cell-free extracts of $P$. pantotrophus NKNCYSA. $\square$, Glutamate; 0 , 3-sulfopyruvate; $\triangle$, sulfite; $O$, ammonia. Data are representative values.

of $\mathrm{NADP}^{+} ; \mathrm{NAD}^{+}$did not support the reaction. We suspected the presence of glutamate dehydrogenase, which we confirmed by direct assay in the (favoured) reverse reaction; the specific activity was about $100 \mathrm{mkat}(\mathrm{kg} \text { protein })^{-1}$. Boiled extract was inactive.

The concentration of sulfate was unaltered during these experiments (data not shown) and sulfite was not detected.

We tried to optimize the standard reaction mixture (Fig. 4) by the addition of the transaminase cofactor, pyridoxal 5'-phosphate, or of ATP for activation, but found no effect. Addition of nitrate was without effect. The buffer system could vary from $\mathrm{pH} 7 \cdot 0$ to $9 \cdot 0$, with either potassium phosphate, Tris/ACES or Tris/ $\mathrm{HCl}$ buffer, with no change in the transamination rate. The temperature, which was varied from 30 to $40^{\circ} \mathrm{C}$, had negligible effect. Disruption of cells and enzyme assays under oxic conditions did not change the specific transamination rate.

We presumed the reaction in Fig. 4 to represent a transaminase at equilibrium. If more cysteate was added after $120 \mathrm{~min}$, more substrate disappeared and more glutamate was formed to attain a new equilibrium (not shown), and neither of the following altered this condition: addition of hydrazine to trap the sulfopyruvate, or lactate dehydrogenase with NADH. Neither sulfite nor additional sulfate was detected. The 
addition of CoA and ATP also did not cause any further reaction.

We examined extracts of cells grown in anoxic acetate/ nitrate/salts medium and taurine/nitrate/salts medium and obtained data essentially identical to those in Fig. 4, so the aminotransferase and the dehydrogenase are synthesized constitutively. Extracts of taurine-grown cells contained a taurine:pyruvate transaminase and formed alanine (not shown), whereas cysteate-grown cells or acetate-grown cells did not, so the taurine:pyruvate transaminase is inducible.

Given an inducible taurine transaminase which is absent in cysteate-grown cells and in acetate-grown cells, we suggest that the initial attack on cysteate is not decarboxylation or any attack on the sulfonate moiety, but a transamination to yield sulfopyruvate.

Extracts of cells grown aerobically in cysteate/salts medium also catalysed an L-cysteate:2-oxoglutarate transamination with a specific activity similar to that in Fig. 4. No release of sulfate or sulfite was detected.

\section{DISCUSSION}

Desulfonation reactions in anaerobic bacteria have been discovered only recently (Seitz \& Leadbetter, 1995; Cook, 1998), but it is already clear that the first recognized dissimilatory reaction, reduction of sulfonates in respirations, is widespread in sulfate-reducing bacteria (Lie et al., 1996, 1998) and in Bilophila wadsworthia in the normal human gut flora (Laue et al., 1997b, 1999). Much less was known about the second recognized class of dissimilatory reactions in anaerobes, the oxidations, where only one organism has been examined in any detail, though others were detected (Denger et al., 1997a). The present work confirms the ease with which rapidly growing sulfonate oxidizers are found amongst nitrate reducers, one of which was identified as a strain of $P$. pantotrophus. Indeed, a culture collection strain (DSM 65) of this species catalyses the nitrate-dependent oxidation of taurine. We have only a preliminary indication of sulfonate oxidation in sulfate-reducing bacteria, but there is strong evidence for the oxidation of cysteate in iron(III)reducing bacteria (Fig. 2). It seems likely that the oxidation of natural sulfonates is widespread in anoxic environments.

We were surprised not to find enrichments able to utilize the ubiquitous natural product methanesulfonate (cf. Kelly, 1996; Kelly \& Murrell, 1996). Our inocula were from the anaerobic digestors of sewage treatment plants, so perhaps no methanesulfonate survives the aerobic stages and no suitable organisms are found in this niche. The widespread occurrence of aerobes able to utilize 4toluenesulfonate (Cook et al., 1998) could explain why no substrate enters the digestor, but the argument does not hold for octylbenzenesulfonate, $20 \%$ of whose commercial analogue linear alkylbenzenesulfonate (LAS) enters the anaerobic digestor (Giger et al., 1989).
Although octylbenzenesulfonate and LAS are bioavailable to some anaerobes under sulfur-limited conditions (Denger et al., 1996; Denger \& Cook, 1999), it is regarded as non-degradable as a source of electrons (Painter \& Mosey, 1992) and our data tend to support this idea, though we were working at a high concentration.

$P$. pantotrophus NKNCYSA differs biochemically from our previous isolate, Alcaligenes sp. strain NKNTAU, in that it has a wider (more than five) and overlapping range of sulfonate substrates; strain NKNTAU oxidizes only taurine (Denger et al., 1997a). The stoichiometry of growth can be considered formally to comprise a dissimilatory and an assimilatory component. Below, we show the presumed dissimilatory component for strain NKNCYSA (see also the second footnote to Table 1), working with published data (Thauer et al., 1977) or with values (cysteate, $-838.2 \mathrm{~kJ} \mathrm{~mol}^{-1}$; isethionate, $-649.8 \mathrm{~kJ} \mathrm{~mol}^{-1}$ ) calculated as described elsewhere (Mavrovouniotis, 1991). The balanced equations require $2.4 \mathrm{~mol} \mathrm{NO}_{3}^{-}$(mol sulfonate) ${ }^{-1}$, in close agreement with the experimental data $\left[2 \cdot 2-2 \cdot 3 \mathrm{~mol} \mathrm{NO}_{3}^{-}\right.$(mol sul-

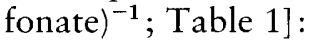

cysteate:

$$
\begin{array}{r}
1 \mathrm{C}_{3} \mathrm{H}_{6} \mathrm{NSO}_{5}^{-}+2 \cdot 4 \mathrm{NO}_{3}^{-}+2 \cdot 4 \mathrm{H}^{+} \rightarrow \\
3 \mathrm{CO}_{2}+1 \mathrm{SO}_{4}^{2-}+1 \mathrm{NH}_{4}^{+}+1 \cdot 2 \mathrm{~N}_{2}+2 \cdot 2 \mathrm{H}_{2} \mathrm{O} \\
\Delta G_{0}^{\prime}=-1327 \cdot 8 \mathrm{~kJ} \mathrm{~mol}^{-1}
\end{array}
$$

taurine:

$$
\begin{aligned}
& 1 \mathrm{C}_{2} \mathrm{H}_{7} \mathrm{NSO}_{3}+2 \cdot 4 \mathrm{NO}_{3}^{-}+1 \cdot 4 \mathrm{H}^{+} \rightarrow \\
& 2 \mathrm{CO}_{2}+1 \mathrm{SO}_{4}^{2-}+1 \mathrm{NH}_{4}^{+}+1 \cdot 2 \mathrm{~N}_{2}+2 \cdot 2 \mathrm{H}_{2} \mathrm{O} \\
& \Delta G_{0}^{\prime}=-1302 \cdot 1 \mathrm{~kJ} \mathrm{~mol}{ }^{-1}
\end{aligned}
$$

isethionate:

$$
\begin{array}{r}
1 \mathrm{C}_{2} \mathrm{H}_{5} \mathrm{SO}_{4}^{-}+2 \cdot 4 \mathrm{NO}_{3}^{-}+1 \cdot 4 \mathrm{H}^{+} \rightarrow \\
2 \mathrm{CO}_{2}+1 \mathrm{SO}_{4}^{2-}+1 \cdot 2 \mathrm{~N}_{2}+3 \cdot 2 \mathrm{H}_{2} \mathrm{O} \\
\Delta \mathrm{G}_{0}^{\prime}=-1319 \cdot 5 \mathrm{~kJ} \mathrm{~mol}^{-1}
\end{array}
$$

acetate:

$$
\begin{aligned}
& 1 \mathrm{C}_{2} \mathrm{H}_{3} \mathrm{O}_{2}^{-}+1 \cdot 6 \mathrm{NO}_{3}^{-}+2 \cdot 6 \mathrm{H}^{+} \rightarrow \\
& 2 \mathrm{CO}_{2}+0 \cdot 8 \mathrm{~N}_{2}+2 \cdot 8 \mathrm{H}_{2} \mathrm{O} \\
& \Delta G_{0}^{\prime}=-801 \cdot 6 \mathrm{~kJ} \mathrm{~mol}^{-1}
\end{aligned}
$$

We observed large differences in molar growth yields [e.g. 2.2 and $6.7 \mathrm{~g}$ protein $(\mathrm{mol} \mathrm{C})^{-1}$ for cysteate and isethionate, respectively], although similar free energy changes are available in each case and we cannot explain this. Perhaps experiments done in carbon-limited continuous cultures would yield less ambiguous data.

$P$. pantotrophus NKNCYSA has a specific growth rate of $0.05 \mathrm{~h}^{-1}$ in cysteate/nitrate/salts medium and a molar growth yield of $6.6 \mathrm{~g}$ protein (mol cysteate) ${ }^{-1}$ (Fig. 3, Table 1), so the specific activity of cysteate turnover in vivo is $2 \cdot 1 \mathrm{mkat}(\mathrm{kg} \text { protein })^{-1}$. Our enzyme preparations (Fig. 4) have a specific activity for cysteate disappearance of 4-5 mkat ( $\mathrm{kg}$ protein $)^{-1}$, which is sufficient to account for the growth rate. The results support a transamination as the first metabolic reaction (see above), so 


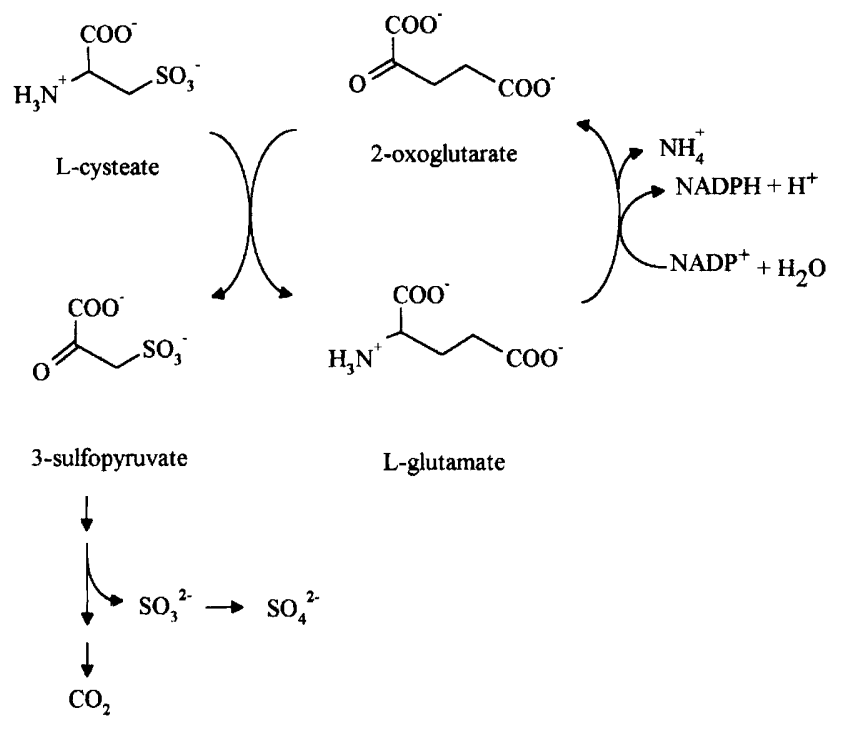

Fig. 5. Anaerobic oxidation of cysteate by $P$. pantotrophus NKNCYSA; known and postulated reactions. Whereas the aminotransferase and oxidative deamination reactions have been established, we must speculate that the desulfonation reaction involves sulfite (all known desulfonations release sulfite; Cook et al., 1998). None of the reactions leading from sulfopyruvate to $\mathrm{CO}_{2}$ is known.

we have observed a previously unknown enzyme, $\mathrm{L}^{-}$ cysteate: 2-oxoglutarate aminotransferase (EC 2.6.1.-) (Fig. 5). The ammonia released into growth medium in cysteate/nitrate/salts medium (Fig. 3) derives from the oxidative deamination of $\mathrm{L}$-glutamate dehydrogenase (Fig. 5) The next enzyme in the pathway from sulfopyruvate is obviously inactive in our preparations, and we hesitate to hypothesize further, with no information to work with.

P. pantotrophus NKNCYSA is facultatively anaerobic and can grow under strictly anoxic conditions. Little is known about the genetic regulation of the dissimilatory pathways for sulfonates in anaerobes. The dissimilation of taurine in B. wadsworthia appears to be constitutive (Laue et al., 1997b), whilst taurine is the only known substrate in the fermentative organism (Denger et al., 1997b), so no conclusion can be drawn. Work with sulfate reducers, especially Desulfovibrio desulfuricans IC1, in which the organism was grown in different sulfonates and extracts of these different cells separated on denaturing protein gels, indicated different bands following growth with different sulfonates (Lie et al., 1998). This strongly implies inducible enzymes. The inducibility of taurine dissimilation in strain NKNCYSA is thus the first known case of induction measured as enzyme activity, and extracts of cells of strain NKNCYSA grown in different sulfonate/nitrate/salts media also yielded different patterns on denaturing protein gels, implying enzyme induction (K. Denger, unpublished), which we wish to explore. In contrast, the constitutive expression of the L-cysteate : 2 -oxoglutarate aminotransferase resembles the pattern in $B$. wads- worthia. We also wish to compare the cysteate:oxoglutarate transaminase(s) expressed in strain NKNCYSA under aerobic and anaerobic conditions.

\section{ACKNOWLEDGEMENTS}

We are grateful to R. H. White for the gift of 3-sulfopyruvate. The research was funded by the University of Konstanz.

\section{REFERENCES}

Bonson, P. P. M., Spudich, J. A., Nelson, D. L. \& Kornberg, A. (1969). Biochemical studies of bacterial sporulation and germination. XII. A sulfonic acid as a major sulfur compound of Bacillus subtilis spores. J Bacteriol 98, 62-68.

Braun, R. \& Fromageot, P. (1962). Désamination de la taurine par Aspergillus niger. Biochim Biophys Acta 62, 548-555.

Chien, C.-C., Leadbetter, E. R. \& Godchaux, W., III (1995). Sulfonate-sulfur can be assimilated for fermentative growth. FEMS Microbiol Lett 129, 189-194.

Cline, J. D. (1969). Spectrophotometric determination of hydrogen sulfide in natural waters. Limnol Oceanogr 14, 454-458.

Consden, R., Gordon, A. H. \& Martin, A. J.P. (1946). The identification of amino-acids derived from cysteine in chemically modified wool. Biochem J 40, 580-582.

Cook, A. M. (1998). Sulfonated surfactants and related compounds: facets of their desulfonation by aerobic and anaerobic bacteria. Tenside Surfactants Deterg 35, 52-56.

Cook, A. M. \& Hütter, R. (1981). $s$-Triazines as nitrogen sources for bacteria. J Agric Food Chem 29, 1135-1143.

Cook, A. M., Laue, H. \& Junker, F. (1998). Microbial desulfonation. FEMS Microbiol Rev 22, 399-419.

Cunningham, C., Tipton, K. F. \& Dixon, B. F. (1998). Conversion of taurine into $\mathrm{N}$-chlorotaurine (taurine chloramine) and sulfoacetaldehyde in response to oxidative stress. Biochem $J \mathbf{3 3 0}$, 939-945.

Denger, K. \& Cook, A. M. (1999). Linear alkylbenzenesulfonate (LAS) bioavailable to anaerobic bacteria as a source of sulfur. $J$ Appl Microbiol 86, 165-168.

Denger, K., Kertesz, M. A., Vock, E. H., Schön, R., Mägli, A. \& Cook, A. M. (1996). Anaerobic desulfonation of 4-tolylsulfonate and 2-(4-sulfophenyl)butyrate by a Clostridium sp. Appl Environ Microbiol 62, 1526-1530.

Denger, K., Laue, H. \& Cook, A. M. (1997a). Anaerobic taurine oxidation: a novel reaction by a nitrate-reducing Alcaligenes sp. Microbiology 143, 1919-1924.

Denger, K., Laue, H. \& Cook, A. M. (1997b). Thiosulfate as a metabolic product: the bacterial fermentation of taurine. Arch Microbiol 168, 297-301.

Denger, K., Stackebrandt, E. \& Cook, A. M. (1999). Desulfonispora thiosulfatigenes gen. nov., sp. nov., a taurine-fermenting, thiosulfate-producing anaerobic bacterium. Int J Syst Bacteriol (in press).

Gerhardt, P., Murray, R. G. E., Wood, W. A. \& Krieg, N. R. (1994). Methods for General and Molecular Bacteriology. Washington, DC: American Society for Microbiology.

Gesellschaft Deutscher Chemiker (1996). German Standard Methods for the Laboratory Examination of Water, Waste Water and Sludge. Weinheim: VCH.

Giger, W., Alder, A. C., Brunner, P. H., Marcomini, A. \& Siegrist, H. (1989). Behaviour of LAS in sewage and sludge treatment and in sludge-treated soil. Tenside Surfactants Deterg 26, 95-100. 
Gregersen, T. (1978). Rapid method for distinction of Gramnegative from Gram-positive bacteria. Eur J Appl Microbiol Biotechnol 5, 123-127.

Huxtable, R. J. (1992). Physiological actions of taurine. Physiol Rev 72, 101-163.

Kelly, D. P. (1996). Perspectives in the microbiology of atmospheric trace gases. In Microbiology of Atmospheric Trace Gases: Sources, Sinks and Global Change Processes, pp. 288-295. Edited by J. C. Murrell \& D. P. Kelly. Berlin: Springer.

Kelly, D. P. \& Murrell, J. C. (1996). Metabolism of methanesulfonic acid. In Microbial Growth on $\mathrm{C}_{1}$ Compounds, pp. 33-40. Edited by M. E. Lidstrom \& F. R. Tabita. Dordrecht: Kluwer.

Kölbener, P., Baumann, U., Leisinger, T. \& Cook, A. M. (1995). Non-degraded metabolites arising from the biodegradation of commercial linear alkylbenzenesulfonate (LAS) surfactants in a laboratory trickling filter. Environ Toxicol Chem 14, 561-569.

Kondo, H., Yazawa, M., Enami, M. \& Ishimoto, M. (1982). Sulfite production from benzenesulfonate by bacterial enzyme compared with taurine. Sulfur Amino Acids 5, 237-242.

Koshikawa, T., Nakashio, S., Kusuyama, K., Ichikawa, T. \& Kondo, M. (1981). Presence of cysteic acid in the sporangium and its metabolic pathway during sporulation of Bacillus subtilis NRRL B558. J Gen Microbiol 124, 415-423.

Laue, H., Field, J. A. \& Cook, A. M. (1996). Bacterial desulfonation of the ethanesulfonate metabolite of the chloroacetanilide herbicide metazachlor. Environ Sci Technol 30, 1129-1132.

Laue, H., Denger, K. \& Cook, A. M. (1997a). Fermentation of cysteate by a sulfate-reducing bacterium. Arch Microbiol 168, 210-214.

Laue, H., Denger, K. \& Cook, A. M. (1997b). Taurine reduction in anaerobic respiration of Bilophila wadsworthia RZATAU. Appl Environ Microbiol 63, 2016-2021.

Laue, H., Schumacher, U. K. \& Cook, A. M. (1999). Taurine reduction powers rapid growth of Bilophila wadsworthia: a liquid minimal-salts medium for clinical research? Anaerobe (in press).

Lie, T. J., Pitta, T., Leadbetter, E. R., Godchaux, W., III \& Leadbetter, J. R. (1996). Sulfonates: novel electron acceptors in anaerobic respiration. Arch Microbiol 166, 204-210.

Lie, T. L., Leadbetter, J. R. \& Leadbetter, E. R. (1998). Metabolism of sulfonic acids and other organosulfur compounds by sulfatereducing bacteria. Geomicrobiol J 15, 135-149.

Luria, S. E. (1960). The bacterial protoplasm: composition and organization. In The Bacteria, vol. 1, pp. 1-34. Edited by I. C. Gunsalus \& R. Y. Stanier. New York: Academic Press.

Maidak, B. L., Olsen, G. L., Larsen, N., McCaughey, M. J. \& Woese, C. R. (1996). The ribosomal database project (RDP). Nucleic Acids Res 24, 82-85.

Mavrovouniotis, M. L. (1991). Estimation of standard Gibbs energy changes of biotransformations. J Biol Chem 266, 1444014445 .

Mikosch, C. A. R. M. (1997). Anaerobe mikrobielle Oxidation sulfonierter Verbindungen. Diplomarbeit, University of Konstanz.

Painter, H. A. \& Mosey, F. E. (1992). The anaerobic biodegradability of linear alkyl benzene sulfonate (LAS). In Proceedings of the 3rd CESIO International Surfactant Congress, 1-5 June 1992, London, pp. 3443.
Pfennig, N. (1978). Rhodocyclus purpureus gen. nov. sp. nov., a ring-shaped, vitamin $\mathrm{B}_{12}$-requiring member of the family Rhodospirillaceae. Int J Syst Bacteriol 28, 283-288.

Rainey, F. A., Ward-Rainey, N., Kroppenstedt, R. M. \& Stackebrandt, E. (1996). The genus Nocardiopsis represents a phylogenetically coherent taxon and a distinct actinomycete lineage: proposal of Nocardiopsaceae fam. nov. Int J Syst Bacteriol 46, 1088-1092.

Rainey, F. A., Kelly, D. P., Stackebrandt, E., Burkhardt, J., Hiraishi, A., Katayama, Y. \& Wood, A. P. (1999). A re-evaluation of the taxonomy of Paracoccus denitrificans and a proposal for the creation of Paracoccus pantotrophus comb. nov. Int J Syst Bacteriol 49, 645-651.

Sanger, F. (1945). The free amino groups of insulin. Biochem J 39, 507-515.

Schauder, R., Eikmanns, B., Thauer, R. K., Widdel, F. \& Fuchs, G. (1986). Acetate oxidation to $\mathrm{CO}_{2}$ in anaerobic bacteria via a novel pathway not involving reactions of the citric acid cycle. Arch Microbiol 145, 162-172.

Schmidt, E. (1974). Glutamat-Dehydrogenase UV-Test. In Methoden der enzymatischen Analyse, pp. 689-696. Edited by H. U. Bergmeyer. Weinheim: Verlag Chemie.

Schwertmann, U. \& Cornell, R. M. (1991). Iron Oxides in the Laboratory. Weinheim: VCH.

Seitz, A. P. \& Leadbetter, E. R. (1995). Microbial assimilation and dissimilation of sulfonate sulfur. ACS Symp Ser 612, 365-375.

Stapley, E. O. \& Starkey, R. L. (1970). Decomposition of cysteic acid and taurine by soil microorganisms. J Gen Microbiol 64, $77-84$.

Stookey, L. L. (1970). Ferrozine - a new spectrophotometric agent for iron. Anal Chem 42, 779-781.

Thauer, R. K., Jungermann, K. \& Decker, K. (1977). Energy conservation in chemotrophic anaerobic bacteria. Bacteriol Rev 41, 100-180.

Tschech, A. \& Pfennig, N. (1984). Growth yield increase linked to caffeate reduction in Acetobacterium woodii. Arch Microbiol 137, 163-167.

Voet, D. \& Voet, J. G. (1992). Biochemie, 1st edn. Weinheim: VCH.

White, R. H. (1986). Intermediates in the biosynthesis of coenzyme M (2-mercaptoethanesulfonic acid). Biochemistry 25, 5304-5308.

Widdel, F. \& Bak, F. (1992). Gram-negative mesophilic sulfatereducing bacteria. In The Prokaryotes, pp. 3352-3378. Edited by A. Balows, H. G. Trüper, M. Dworkin, W. Harder \& K. H. Schleifer. Berlin: Springer.

Widdel, F. \& Pfennig, N. (1981). Studies on dissimilatory sulfatereducing bacteria that decompose fatty acids. I. Isolation of new sulfate-reducing bacteria enriched with acetate from saline environments. Description of Desulfobacter postgatei gen. nov., sp. nov. Arch Microbiol 129, 395-400.

Widdel, F., Kohring, G. W. \& Mayer, F. (1983). Studies on dissimilatory sulfate-reducing bacteria that decompose fatty acids. III. Characterization of the filamentous gliding Desulfonema limicola gen. nov., sp. nov., and Desulfonema magnum sp. nov. Arch Microbiol 134, 286-294.

Received 2 October 1998; revised 21 January 1999; accepted 2 February 1999. 